\title{
MENELAAH TEORI VYGOTSKY DAN INTERDEPEDENSI SOSIAL SEBAGAI LANDASAN TEORI DALAM PELAKSANAAN PEMBELAJARAN KOOPERATIF DI SEKOLAH DASAR
}

\author{
Yayu Tresna Suci \\ Universitas Pendidikan Indonesia \\ Jalan Setiabudhi No. 229, Isola, Sukasari, Isola, Sukasari, Kota Bandung, Jawa Barat 40154 \\ Email: tresnasuci.yts@gmail.com
}

\begin{abstract}
Abstrak
Pembelajarn kooperatif memiliki popularitas yang membumi di dunia pendidikan. Penelitian mengenai keunggulan pembelajaran kooperatif banyak ditemukan dan membawa angin segar bagi peningkatan kualitas pembelajaran di sekolah. Dewasa ini pembelajaran kooperatif diharapkan bisa menjadi ruh dalam setiap aktivitas belajar di sekolah, akan tetapi pada pelaksanaanya tidak sedikit guru yang salah memberikan persepsi tentang pembelajaran kooperatif dan cenderung kesulitan dalam menerapkannya di kelas mereka. Tulisan ini mencoba membangun pembelajaran kooperatif dari segi teoritis yaitu melalui pemikiran vygotsky dan teori interdepedenncy social. Kedua teori ini akan ditelaah secara sistematis guna memberikan gambaran bagaimana wujud pembelajaran kooperatif yang lebih memadai.
\end{abstract}

Kata kunci:

Pembelajaran kooperatif, teori vygotksy, teori interdepedency social.

\begin{abstract}
Cooperative learning has a grounded popularity in the world of education. Research on the advantages of cooperative learning is found and brings fresh air to improve the quality of learning in schools. Today cooperative learning is expected to be a spirit in every learning activity in schools, but in practice there are not a few teachers who mistakenly give perceptions about cooperative learning and tend to have difficulties in applying it in their classrooms. This paper tries to build cooperative learning from a theoretical point of view, namely through vygotsky thinking and social interdependent theory. Both of these theories will be systematically reviewed in order to provide an overview of the more adequate form of cooperative learning.
\end{abstract}

Keywords:

Cooperative learning, vygotksy theory, social interdepedency theory.

\section{A. PENDAhULUAN}

Penunjang utama progresifitas sumber daya manusia adalah pendidikan, proses pembentukan manusia yang seutuhnya akan terfasilitasi melalui sistem pendidikan yang ideal. Pondasi pembentukan tersebut dimulai dari masa anak-anak, menurut Rosseuau (Desmita, 2010:15) 'anak merupakan makhluk yang utuh dan terintegrasi'. Berkaitan dengan pendapat Rosseuau, penulis menarik kesimpulan bahwa anak merupakan makhluk yang utuh dengan segala potensi luar biasa dan terintegrasi oleh faktor nature dan nurture dalam segala aspek perkembanganya. Sedangkan menurut Sadulloh (2007:110) "anak didik merupakan seseorang yang sedang berkembang, memiliki potensi tertentu, dan dengan bantuan pendidik ia mengembangkan potensinya tersebut secara optimal". Lebih lengkap lagi Tilaar (2013) memandang bahwa anak adalah individu yang otonom memiliki keunikan dan memerlukan eksistensi dengan proses individuasi dan partisipasi dengan lingkungannya. Individuasi adalah proses menunjukkan keunikan diri, sedangkan partisipasi adalah keterlibatan diri yang positif dalam lingkungan belajar. Dengan demikian dapat ditarik kesimpulan bahwa anak didik memerlukan pendidikan yang mampu memberinya kesempatan untuk mengaktualisasikan dirinya dengan segala 
potensi yang dimiliki agar senantiasa berkembang optimal baik secara fisik, kognitif, afektif, psikomotor, social, bahasa, moral, dan spiritualnya.

Percepatan perkembangan terjadi pada masa anak-anak. Salah satu tugas perkembangan anak usia sekolah dasar yang sangat esensial adalah perkembangan social. Menurut Vygotsky (Suprijono, 2010:55) 'siswa berada dalam konteks sosiohistoris, pengalaman dalam konteks social memberikan mekanisme penting untuk perkembangan pemikiran siswa'. Selanjutnya menurut Piaget (Slavin, 2010:37) 'pengetahuan tentang perangkat social, bahasa, nilai-nilai, peraturan, moralitas, dan system symbol (seperti membaca dan matematika) hanya dapat dipelajari dalam interaksi dengan orang lain'. Berdasarkan kedua pendapat dari Vygotsky dan Piaget dapat ditarik kesimpulan bahwa terdapat korelasi antara perkembangan belajar dan perkembangan sosial. Siswa dapat memperoleh seperangkat pengetahuan apabila mereka dikondisikan dalam proses belajar yang melibatkan interaksi dialogis pada sebuah kelompok yang heterogen atau lebih dikenal dengan pembelajaran kooperatif (Cooperative Learning). Mendesain dan melaksanakan pembelajaran kooperatif tidaklah mudah, seorang guru harus memiliki pengetahuan secara teoritis maupun praktis dalam bidang psikologi pendidikan dan managemen kelas. Kajian psikologi pendidikan akan mengupas mengenai teoriteori belajar kognisi sosial, sedangkan kajian management kelas akan mengupas mengenai bagaimana cara guru dalam mengelola kelompok belajar agar kohesif dan mampu menciptakan iklim belajar yang kooperatif dan interaktif. Atas dasar tersebut, penulis berkeinginan untuk mengkaji bagaimana konstruksi teori belajar Vygotsky dan interdepedency social berkontribusi dalam pelaksanaan pembelajaran kooperatif.

\section{B. PEMBAHASAN \\ 1. Teori Vygotsky}

Lev Semenovich Vygotsky merupakan cendekia yang berasal dari Rusia, dia seorang ahli dalam bidang psikologi, filsafat, dan sastra. Filosofi Vygotsky yang sangat terkenal adalah mengenai manusia dan lingkungan, menurut Vygotsky 'manusia tidak seperti hewan yang hanya bereaksi terhadap lingkungan, manusia memiliki kapasitas untuk mengubah lingkungan sesuai keperluan mereka' (Schunk, 2012 : 338). Pemikiran filosofis Vygotsky mengenai manusia kemudian menjadi pelopor lahirnya teori konstruktivisme sosial yang artinya membangun kognitif anak melalui interaksi sosial. Vygotsky sangat tertarik mengupas esensi dari serangkaian aktivitas bermakna di lingkungan social-kultural dalam memperngaruhi konstruksi kognitif seorang anak. Maka dari itu pemikiran vygotsky sering disebut sebagai perspektif sosiokultural.

Asumsi dasar dari teori konstruktivisme sosial Vygotsky adalah "What the child can do in cooperation today he can do alone tomorrow". (Warsono, 2012: 59). Apa yang dilakukan atau dipelajari anak hari ini dengan bekerja sama (kelompok) dapat diakukannnya secara mandiri pada masa yang akan datang. Menurut Vygotsky, (Arends, 2008:47) 'pelajar memiliki dua tingkat perkembangan berbeda : tingkat perkembangan aktual dan tingkat perkembangan potensial'. Tingkat perkembangan aktual terjadi ketika ketika individu mandiri dalam menggunakan kemampuan kognitifnya secara fungsional. Selanjutnya perkembangan potensial merupakan tingkatan kognitif yang bisa dicapai oleh anak-anak melalui bantuan orang dewasa seperti guru, orang tua, atau teman sebaya yang lebih kompeten. Atas dasar asumsi tersebut, Vygotsky menyarankan agar guru bisa berkolaborasi dengan siswa serta memfasilitasinya untuk membangun pengetahuan dengan diskusi, tanya jawab, bahkan berdebat dengan teman sebaya. 
Menurut Vygotsky, anak-anak pada awal perkembangannya membangun kognitifnya melalui proses mental yang rendah, contohnya yaitu persepsi sederhana mengenai suatu objek, belajar asosiatif (pengelompokkan), dan perhatian atau arahan terbimbing yang diberikan oleh orang tua sejak balita. Pengembangan kognitif berlanjut dengan proses mental yang lebih tinggi, kemampuan berbahasa, berhitung, berfikir, mengingat, pemecahan masalah, perhatian spontan, intuisi, dan skema memori dapat diperoleh dan ditingkatkan melalui interaksi sosial seperti berdialog dan bermain.

Untuk mencapai tahapan kognitif yang lebih tinggi, anak-anak sangat membutuhkan partner yang lebih berkompeten misalnya orang tua, guru, kakak, atau teman sebaya yang lebih pintar. Selain partner untuk berkolaborasi, anak-anak juga memerlukan tugas yang menantang agar membantu perkembangan kognitifnya. Melalui kolaborasi dengan orang tua dan teman sebaya serta difasilitasi oleh tugas yang menantang, anak akan memperoleh perangkat-perangkat kognitif seperti bahasa, symbol, peta, gambar, obrolan, serta pemecahan masalah. Pada saat anak terampil mengolah perangkat kognitif mereka melalui aktivitas-aktivitas social, maka peningkatan kemampuan kognitifnya pun niscaya meningkat. Menurut Ormrod (2008:57) "proses berkembanganya aktivitasaktivitas social menjadi aktivitas-aktivitas mental internal disebut internalisasi". Dalam segala aktivitas sosialnya dengan guru, orang tua, maupun teman sebaya, anak-anak senantiasa menginternalisasikan setiap arahan yang mereka peroleh sehingga pada akhirnya mereka mampu memberikan arahan pada diri sendiri untuk menyelesaikan tugas belajarnya.

Untuk memfasilitasi proses internalisasi tersebut Vygotksy mengetengahkan suatu wilayah diantara perkembangan actual dan potensial, yang disebut zone of proximal development (ZPD). Selasaras dengan pernyataan Schunk (2008:341) yang menyatakan bahwa ZPD didefinisikan "sebagai jarak antara level perkembangan actual yang ditentukan melalui pemecahan masalah secara mandiri dan level potensial perkembangan yang ditentukan melalui pemecahan masalah dengan bantuan orang dewasa atau dengan kerja sama dengan teman sebaya yang lebih mampu". ZPD dimaknai juga sebagai zona belajar yang mampu dijangkau oleh anak-anak, zona actual terlalu mudah sehingga menyebabkan stagnan kemampuan kognitif siswa, sebaliknya zona potensial terlalu sulit dijangkau siswa meskipun dengan bantuan orang dewasa, sehingga dampaknya adalah frustasi.
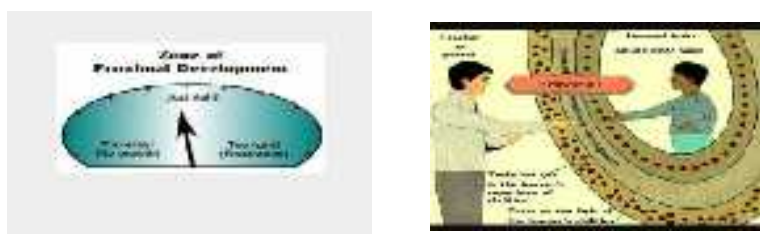

Gambar 1.

\section{Zona of Proximal Development}

Dalam membangun ZPD guru dan siswa berkolaborasi dalam sebuah penyelesaian tugas terstruktur yang menantang siswa, sehingga bantuan dari guru atau teman sebaya yang lebih mumpuni akan sangat membantu. Jika anak kemudian mampu mengatasi kesulitannya secara mandiri dengan dibantu oleh guru atau teman sebaya yang lebih mumpuni, maka bersamaan dengan itu level kognitifnya meningkat. Seorang anak akan mencapai tingkat kognitif yang lebih tinggi jika anak perlahan mulai dapat mengurangi ketergantungan terhadap orang lain dalam pemecahan masalah.

Schunk, (2012 : 339) menegaskan bahwa "aspek-aspek cultural-historis dari teori Vygotsky menonjolkan pemikiran bahwa pembelajaran dan perkembangan tidak dapat dipisahkan dari konteksnya. Cara siswa berinteraksi dengan dunia mereka, orangorang, objek, dan intuisi-intuisi di dalamnya mengubah cara berfikir mereka". Berdasarkan penjabaran mengenai aspek-aspek culturalhistoris dari teori Vygotsky yang dikemukakan oleh Schunk, penulis berpendapat bahwa sudah seharusnya sekolah 
sebagai lingkungan sosial pedagogis mampu memberikan ruang bagi siswa untuk melakukan interaksi. Kemampuan berkomunikasi dan berinteraksi siswa dengan lingkungan sosial merupakan aktivitas bermakna yang akan mengkonstruk beragam pengetahuan.

Teori Vygotsky bisa diaplikasikan oleh seorang guru di dalam kelas, guru bisa menerapkan model pembelajaran yang memungkinkan siswa untuk berkolaborasi dengan teman sebaya dalam kelompok kecil. Salah satu pembelajaran yang memungkinkan terciptanya iklim kelas yang interaktif dan kolaboratif adalah Pembelajaran kooperatif. Pembelajaran kooperatif memungkinkan siswa untuk menjalin hubungan interaksi sosial dengan teman sebaya yang lebih berkompeten melalui arahan dan bimbingan dari guru. Iklim kelas dalam Pembelajaran kooperatif dapat memfasilitasi siswa dalam membangun kualitas berpikir serta membangun kultur sosialnya dalam pembelajaran berkelompok. Oleh karena itu dapat ditarik kesimpulan bahwa teori Vygotsky merupakan salah satu teori yang melandasi pelaksanaan pembelajaran kooperatif di dalam kelas.

\section{Pembelajaran Kooperatif dan Teori Interdepedensi Sosial}

Pembelajaran kooperatif yang dikonstruksi oleh hubungan antara teori, riset dan pelaksanaan. Pada tulisan ini penulis berusaha memberikan gambaran pembelajaran kooperatif yang lebih memadai dengan menonjolkan komponen-komponen di dalamnya serta mengangkat teori interdepensi social sebagai elemen penting dalam pembelajaran kooperatif.

Teori Interdepedensi sosial menyediakan dasar pemikiran pada sesuatu yang akan dibangun oleh pembelajaran kooperatif. Tulisan ini disadur dari karya dua bersaudara yaitu DW Johnson \& R. Johnson. Kedua bersaudara ini merupakan pengembang pembelajaran kooperatif dengan temuannya yaitu mengenai metode Learning Together dan Constructive Contriversion. Menurut Johnson dan Johnson pembelajaran kooperatif tidak bisa disamakan dengan pembelajaran kelompok, pembelajaran kelompok akan terlihat layaknya pembelajaran kooperatif jika memenuhi kelima unsure berikut :

a. Saling ketergantungan positif, yaitu anggota tim terikat untuk bekerja sama satu sama lain dalam mencapai tujuan pembelajran. Jika ada anggota tim yang gagal mengerjakan bagiannya, setiap orang anggota tim lainnya akan memperoleh konsekuensinya. (swim or sink together)

b. Tanggung jawab individu, yaitu seluruh siswa dalam tim bertanggung jawab untuk mengerjakan bagian tugasnya sendiri serta wajib menguasai seluruh materi pembelajaran.

c. Interaksi tatap muka, walaupun setiap anggota tim secara perorangan mengerjakan tugas bagiannya sendiri, sejumlah tugas harus dikerjakan secara interaktif, masing-masing memberikan masukan, penalaran dan kesimpulan, dan lebih penting lagi mereka saling mengajari dan memberikan dorongan satu sama lain.

d. Penerapan keterampilan kolaboratif, di mana siswa didorong dan dibantu untuk mengembangkan rasa saling percaya, kepemimpinan, pengambilan keputusan, komunikasi dan keterampilan mengelola konflik.

e. Proses kelompok, di mana anggota tim menetapkan tujuan kelompok, secara periodic menilai hal-hal yang tercapai dengan baik dalam tim, serta mengidentifikasi perubahan yang harus dilakukan agar ke depan tim dapat berfungsi lebih efektif. (Warsono, 2012:168).

Berdasarkan kelima unsur yang telah dikemukakan oleh Johnson \& Johnson, dapat ditarik kesimpulan bahwa pembelajaran kooperatif memiliki karakter yang khas. Karakter pembelajaran kooperatif dapat terlihat dari individu-individu yang bekerja di dalam satu kelompok, mereka bekerja sama 
untuk mencapai tujuan yang telah disepakati bersama. Di dalam pembelajaran kooperatif harus tercipta saling ketergantungan sosial antara anggota kelompok. Saling ketergantungan sosial bisa diciptakan dengan keterikatan tugas yang melibatkan semua individu dalam kelompok. Setiap individu memiliki tanggung jawab tugas yang menyangkut kepentingan kelompok. Jika salah satu individu lalai dalam mengerjakan tugasnya, konsekuensi akan diterima seluruh anggota kelompok. Kunci dari pembelajaran kooperatif adalah kesadaran akan tanggung jawab terhadap tugas yang dibutuhkan kelompok demi mencapai keberhasilan. Oleh karena sebelum pengerjaan tugas dimulai, sudah seharusnya guru perlu memberikan penekanan atau nasehat akan pentingnya kerjasama tim dan ketergantungan sosial yang positif.

Ahli lain seperti Spencer Kagan melakukan pengembangan pembelajaran kooperatif dari segi struktur pembangunan kelompok dan kelas yang kooperatif. Menurut Kagan (Warsono, 2012:170) 'pembelajaran kooperatif memiliki prinsipprinsip dasar yang perlu dimengerti oleh guru secara mendalam sebagai landasan dalam pelaksanaan pembelajaran kooperatif. Keempat prinsip dasar dalam pembelajaran kooperatif diantaranya yaitu :

a. Positive Interdependence, akan terjadi bila perolehan setiap siswa secara individu terkait dengan perolehan semua anggota dalam kelompoknya. Saling ketergantungan positif yang terkuat akan diraih bila prestasi kelompok tidak mungkin terjadi tanpa kesuksesan dan kontribusi setiap anggota tim.

b. Individual Accountability, setiap anggota kelompok bertanggung jawab untuk meningkatkan kecakapan dan kinerja anggota kelompok yang lain maupun meningkatkan kinerja kelompok secara keseluruhan. Penilaian dilakukan terhadap individu maupun terhadap kelompok.

c. Equal Participation, siswa belajar karena interaksinya dengan materi pembelajaran, oleh sebab itu adanya partisipasi yang setara merupakan hal yang penting bagi kesuksesan seluruh siswa. Untuk membangun kesetaraan partisipasi harus diupayakan pergiliran pembagian tugas antar siswa secara berkala.

d. Simultaneous Interaction, interaksi antar siswa harus selalu dilaksanakan dan berlangsung serentak. Pembelajaran tradisioanal melupakan hal ini karena umumnya guru mendominasi sekitar $80 \%$ pembicaraan.

Berdasarkan keempat prinsip-prinsip yang telah dikemukakan oleh Kagan dapat ditarik kesimpulan bahwa dalam pembelajaran koopertatif, saling ketergantungan sosisal secara positif antar anggota kelompok merupakan prinsip utama yang menjadi bibit pengembang prinsip yang lainnya. Ketika saling ketergantungan positif sudah dapat ditanamkan pada individu di dalam kelompok kooperatif, maka prinsip seperti tanggung jawab individu, kesetaraan partisipasi, dan interaksi sosial akan tercipta secara terintegrasi.

Teori Interdependensi Sosial merupakan teori yang membahas mengenai perasaan saling ketergantungan sosial antar individu dalam konteks pembelajaran. Saling ketergantungan sosial terjadi ketika hasil dari individu dipengaruhi oleh mereka sendiri dan tindakan orang lain (DW Johnson \& R. Johnson, 1989). Menurut Johson bersaudara ada dua jenis saling ketergantungan sosial : 1) positif (ketika tindakan individu mempromosikan prestasi tujuan bersama) dan 2) negatif (bila tindakan individu menghambat pencapaian tujuan masingmasing).

Saling ketergantungan sosial dapat dibedakan dari ketergantungan sosial, kemandirian, dan ketidakberdayaan. Ketergantungan sosial ada saat pencapaian tujuan si A dipengaruhi oleh tindakan si B,bukan sebaliknya. Kemandirian sosial terjadi ketika pencapaian tujuan si A tidak dipengaruhi oleh tindakan si $\mathrm{B}$ dan sebaliknya 
- Ketidakberdayaan sosial terjadi ketika si A atau si B tidak dapat mempengaruhi pencapaian tujuannya satu sama lain. Dasar premis teori interdependensi sosial adalah bagaimana peserta memiliki tujuan yang terstruktur menentukan cara mereka berinteraksi dan pola interaksi menentukan hasil dari situasi belajar. Saling ketergantungan positif menciptakan beberapa proses psikologis diantaranya:

a. Substitusi ( yaitu, sejauh mana tindakan satu orang menggantikan tindakan orang lain ),

b. Cathexis Positif (yaitu , investasi energi positif secara psikologis dalam obyek di luar diri sendiri, seperti temanteman , keluarga, dan pekerjaan ), dan

c. Inducibility ( yaitu, keterbukaan dipengaruhi oleh dan untuk mempengaruhi orang lain ).

(Deutsch ( 1949, 1962).

Hasil saling ketergantungan dalam situasi sosial atau kelompok cenderung menghasilkan peningkatan prestasi dan produktivitas. Saling ketergantungan meliputi sumber daya, peran, dan tugas saling ketergantungan. Sumber daya dapat dibagi antara anggota kelompok seperti jigsaw puzzle . Peran seperti pembaca, perekam , ringkasan , dan pemberi semangat partisipasi dapat diberikan kepada anggota kelompok .Tugas yang diberikan dapat dibagi sehingga setiap anggota kelompok bertanggung jawab untuk melakukan satu aspek dari tugas. Saling ketergantungan social secara positif bisa mengikat anggota kelompok bersamasama dan menghasilkan perasaan tanggung jawab. (DW Johnson \& R. Johnson 2008) menegaskan "Saling ketergantungan social secara positif yang mengikat kelompok anggota bersama-sama yang mengemukakan menghasilkan perasaan tanggung jawab untuk (a) menyelesaikan pekerjaan yang menjadi tugas individu dan (b) memfasilitasi dan membantu anggota kelompok yang lain untuk menyelesaikan tugasnya". Rasa tanggung jawab pada kelompok akan menguatkan akuntabilitas kelompok untuk berjalan bersama-sama dalam kondisi apapun, menang bersama, kalah pun bersama. Jika akuntabilitas kelompok dan individu meningkat, maka rasa tanggung jawa terhadap keberhasilan kelompok akan menguat.

Saling ketergantungan social secara positif juga akan mengasah keterampilan sosial dalam membentuk dasar perhubungan positif antara individu-individu. Dalam meningkatkan rasa saling ketergantungan sosial, guru perlu melakukan pengolahan kelompok yang dapat meningkatkan kesadaran anggota bahwa kelompok tersebut memiliki sumber daya yang dibutuhkan untuk berhasil dan dengan demikian efektivitas secara kolektif harus ditingkatkan serta yang paling penting adalah focus terhadap tujuan. Untuk mengkoordinasikan focus terhadap tujuan, siswa harus :

1) saling mengenal dan saling percaya,

2) berkomunikasi akurat dan jelas,

3) menerima dan mendukung satu sama lain, dan

4) menyelesaikan konflik secara konstruktif

( DW Johnson , 2009 ; D.W. Johnson \& Johnson F. , 2008) .

Selain focus terhadap tujuan bersama, saling ketergantungan social secara positif akan tercipta jika individu-individu di dalamnya memiliki etos kerja yang tinggi dan jauh dari karakter social loafing (pengangguran social). Oleh karena dalam teori interdepedensi sosial bukan hanya mementingkan kerja tim yang positif, tetapi kinerja individu juga harus positif. Upaya Individualistis dapat melengkapi usaha kooperatif melalui pembagian kerja di mana setiap orang focus pada materi atau keterampilan yang menjadi bagiannya untuk selanjutnya digunakan dalam kegiatan kooperatif.

Untuk dapat menciptakan rasa saling ketergantungan sosial secara positif dalam pembelajaran kooperatif formal, guru perlu melakukan hal berikut (Johnson \& Johnson 2008) : 
a. Membuat sejumlah keputusan prainstructional . Seorang guru memiliki untuk memutuskan tujuan pelajaran ( baik akademis dan keterampilan sosial tujuan ), ukuran kelompok , metode menugaskan siswa untuk kelompok , para siswa akan peran ditugaskan, bahan baku yang dibutuhkan untuk melakukan pelajaran dan cara ruangan akan diatur .

b. Jelaskan tugas dan saling ketergantungan yang positif . Seorang guru harus jelas dalam mendefinisikan tugas, mengajarkan konsep yang diperlukan dan strategi pemerolehannya, menentukan saling ketergantungan positif dan akuntabilitas individu , memberikan kriteria untuk sukses, dan menjelaskan keterampilan sosial yang diharapkan pada setiap siswa yang akan terlibat.

c. Memonitor proses belajar siswa dan kontribusinya dalam kelompok untuk memberikan bantuan tugas, membantu siswa meningkatkan kecerdasan interpersonal dan keterampilan berkelompok. Seorang guru secara sistematis mengamati dan mengumpulkan data pada masing-masing kelompok ketika bekerja sama. Jika diperlukan , guru campur tangan untuk membantu siswa dalam menyelesaikan tugas secara akurat dan bekerja sama secara efektif .

d. Evaluasi belajar siswa dan membantu proses siswa seberapa baik kelompok mereka berfungsi . Hasil belajar siswa dengan hati-hati dinilai, dan kinerja mereka dievaluasi . Guru juga menilai anggota kelompok belajar kemudian memproses seberapa efektif mereka telah bekerja sama.

Selain poin-poin di atas, untuk meningkatkan rasa saling ketergantungan social secara positif diperlukan juga pembagian tugas yang jelas dan heterogen bukan tugas yang bersifat tunggal. Seperti penelitian yang dilakukan oleh Latane, William, dan Harkins, 1979) yang memperoleh kesimpulan "dalam kelompok yang tidak memasukkan tanggung jawab indicidu, satu atau dua orang anggota kelompok mungkin akan mengerjakan tugas kelompok, sementara yang lainnya hanya bermalas-malasa. Oleh karena itu kelompok harus diberi tugas yang menekankan peran dan tanggung jawab individu untuk kepentingan kelompok. Jenis tugas tunggal atau penyelesaian masalah harus dihindari. Secara lebih jelas Arends (2008:27) menegaskan :

"untuk membantu siswa bekerja sama dibutuhkan perhatian pada jenis tugas yang diberikan kepada kelompokkelompok kecil. Selain itu juga, dituntut agar guru juga mengajarkan berbagai keterampilan sosial dan kelompok seperti : Interdepedensi, keterampilan sosial, keterampilan berbagi, keterampilan partisipasi, keterampilan komunikasi, dan keterampilan berkelompok".

Guru sering meremehkan pembelajaran kooperatif, salah satu tindak peremehan adalah menyandingkan dengan pembelajaran kelompok yang dependen. Pembelajaran kelompok dengan tugas dependen hanya menggunakan kelompok sebagai topeng dari kegiatan belajar yang terbatas pada interaksi tanya jawab. Tidak ada akuntabilitas pribadi yang dapat menjadi pendorong tumbuhnya akuntabilitas kelompok. Oleh karena itu agar pembelajaran kelompok dapat menjalin kerja sama yang kooperatif, perlu dan penting ditanamkan bahwa setiap individu mempunyai peran penting dan saling tergantung satu sama lain.

Kemudian Arends (2008:28) mengemukakan bahwa : "diferensiasi peran adalah cara lain untuk menstrukturisasikan interdependensi". Diperensiasi peran perlu diterapkan dalam pemberian tugas pembelajaran kooperatif. Melalui perbedaan peran siswa akan saling tergantung secara positif dalam pengerjaan tugas. Contoh diferensi sosial yang berfokus pada 
pengerjaan tugas menurut Arends (2008:24) yaitu:

a. Taskmaster - menjaga agar para anggota kelompok tetap pada tugasnya

b. Material monitor - mengambil dan mengembalikan bahan-bahan

c. Coach helper - membantu para anggota dalam hal isi pelajaran

d. Recorder - mencatat ide-ide, rencanarencana, dan lain-lain.

Berdasarkan serangkaian pendapat yang dikemukakan Arends, penulis menarik kesimpulan bahwa kebanyakan guru mengalami kesulitan dalam menerapkan pembelajaran kelompok yang memenuhi kaidah dan prinsip pembelajaran kooperatif. Salah satu prinsip yang sangat fundamental yaitu saling ketergantungan sosial yang positif dalam membangun akuntabilitas dan kerjasama produktif dari setiap anggota kelompok belajar. Oleh karena itu guru seharusnya membangun pengetahuan secara teoritis maupun praktis mengenai bagaimana menerapkan prinsip-prinsip pembelajaran kooperatif dengan baik agar membantu siswa meningkatkan kemampuan interpersonalnya.

\section{SIMPULAN}

Pembelajaran kooperatif telah banyak digunakan dan diteliti oleh para guru di seluruh negara, tidak terkecuali di Indonesia. Telah banyak mahasiswa keguruan dan ilmu pendidikan menggunakan model pembelajaran kooperatif sebagai topik penelitiannya, tetapi ironisnya penggunaan model pembelajaran kooperatif hanya digunakan untuk keperluan penelitan, setelah penelitian selesai maka berakhirlah pembelajaran kooperatif dan hanya menghasilkan rekomendasi semu bagi sekolah.

Pembelajaran kooperatif dibangun oleh teori konstruktivisme social dari vygotsky. Kondisi sosio kultural dalam bentuk interaksi social dengan guru dan teman sebaya akan membantu anak dalam membangun kemampuan kognitifnya, Asumsi dasar
Vygotsky yaitu apa yang dilakukan oleh anak secara bersama-sama hari ini, suatu hari nanti ia akan mampu melakukannya sendiri. Selain teori Vygotksy pembelajaran kooperatif juga ditunjang oleh teori saling ketergantungan social secara positif (interdependency social). Pembelajaran kooperatif harus terorientasi pada pembentukan rasa saling bergantung secara social antara individu di dalam suatu kelompok belajar. Rasa ketergantungan social akan memupuk rasa tanggung jawab, akuntabilitas, kohesifitas, serta semangat belajar setiap individu dalam kelompok tersebut. Mengingat betapa banyaknya manfaat pembelajaran kooperatif bagi perkembangan kognitif dan sosial siswa, sudah seharusnya lembaga pendidikan memberikan pembekalan dan pengawasan terkontrol terhadap guru-guru di seluruh Indonesia agar mulai menjelajahi beragam pendekatan dan teknik dari pembelajaran kooperatif. Dengan makin banyaknya guru yang menggunakan pembelajaran kooperatif, penulis yakin bahwa pendidikan di Indonesia perlahan akan mengalami perbaikan dari segi kualitas proses pendidikan.

\section{DAFTAR PUSTAKA}

Arends, R.I. (2008). Learning to Teach. Yogyakarta : Pustaka Pelajar

Desmita. (2010). Psikologi Perkembangan. Bandung : Rosda

Johnson, D.W \& Johnson, R.T. (2009). An Educational Psychology Success Story: Social Interdependence Theory and Cooperative Learning. K@ta : American Educational Reasearch Association.

Kojulin, A. (2004). Vygotsky's Theory in The Classroom.K@ta : European Journal of Psychology of Education. Vol XIX 3-7.

Ormrod, E. (2008). Psikologi Pendidikan (Membantu Siswa Tumbuh dan Berkembang). Jakarta : Erlangga. 
Sadulloh, U. (2007). Pedagogik. Bandung : Alfabeta

Schunk.(2012). Learning Theories An Educational Perspective. Yogyakarta : Pustaka Pelajar.

Slavin, R. (2010). Cooperative Learning. Jakarta : Nusamedia
Suprijono, A.(2009). Cooperative Learning Teori \& Aplikasi PAIKEM. Yogyakarta : Pustaka Pelajar

Tilaar. (2012). Perubahan Sosial dalam Perspektif Pedagogik Transformatif. Jakarta : Rineka Cipta

Warsono \& Hariyanto. (2012). Pembelajaran Aktif Teori dan Assesmen. Bandung : Rosda 